\title{
Kinga Dudzińska
}

Polish Institute of International Affairs, Poland

\section{Maciej Raś}

University of Warsaw, Poland

\section{THE QUESTION ABOUT PUBLIC POLICY IN CASE OF THE KALININGRAD OBLAST: RUSSIAN EXCLAVE VS. ENCLAVE SURROUNDED BY THE EUROPEAN UNION ${ }^{1}$}

\begin{abstract}
The problem of enclaves/enclaves in the theory of IR opens an interesting field of study, not only because of the actual phenomena and processes accompanying the formation of said entities, but also due to inaccuracies and variances in the very terms in use, especially in the field of public policy. The Kaliningrad Oblast is either an enclave (from the point of view of the EU, NATO, as well as Poland and Lithuania), or an exclave (from the point of view of the Russian Federation). The status of the region as perceived by the Western countries and organisations differs from the Russian standpoint. The Kaliningrad Oblast always would be a region of external influences of the West, an element of their foreign, security and economic policies, while for Russia Kaliningrad is a sphere of its domestic governance, although shaped by many international determinants resulting from its geographical location. This paper is aimed at examining public policy of the EU and neighbouring countries towards the Kaliningrad Oblast in the context of its specific geographical location and legal status. Possibilities of the region's incorporation in the EU's neighbourhood is also emphasized in the paper as an important factor affecting the position of the Kaliningrad Oblast.
\end{abstract}

\section{Key words}

EU, The Kaliningrad Oblast, public policy

1 The opinions or assertions contained herein are private views of the authors and are not to be construed as official. 